\title{
The Fictional Neurologist
}

Can. J. Neurol. Sci. 2007; 34: 124-125

"Aren't you even going to open it?"

"I might," I tell Ken. "In time."

There sits my envelope at the center of the coffee table. At the center of the envelope sits that white label I neatly stuck on eight months ago with my name and address. It's one of my selfaddressed stamped envelopes. My SASE, as they call them. The publishers have had to stick on an extra one cent stamp though. Postal rates have gone up since I sent them the manuscript of my novel.

Michelle and Lois sip their wine. Lois is the host this month for our writers' group meeting. She's very much into metafiction. In the novel she's working on, things happen out of order and the characters keep asking questions of her, the writer. Sometimes she'll let them in on things that happened in chapters they weren't in.

"When did this come?" Lois asks me.

"I popped home after work to let the dog out and the letter was there in my mailbox. I thought I'd just bring it along to our meeting."

Lois picks up the envelope and holds it to the light. "Can't make out anything this way," she says.

"I know. I already tried that."

"It feels heavier than the usual rejection letter," says Michelle, who's now tossing the envelope from hand to hand.

"Why would an acceptance be any heavier?" asks Ken.

"Dunno," says Michelle. "Maybe there's a multi-million dollar contract inside." She tosses it back onto the coffee table.

"You'd think for an acceptance they'd at least splurge and use their own envelope," Lois suggests.

I sigh. "I'm sure it's just another rejection letter. Sometimes I wonder why I even bother writing fiction."

"Yeah," says Michelle, "Neurology's a decent day job. Why do you bother?"

"I don't know. I guess I just have to. In a way, writing fiction is what I do in neurology too. I have to take the patient's story and turn it into some kind of semi-coherent narrative. What I write down is never quite the story I hear. I have to prune a lot, leaving out things the patient might think are important just because I don't agree. In the end, my consultation letter is kind of a whodunnit, trying to blame the symptoms on some villainous lesion or other."

"But that's not fiction," says Ken, "maybe creative nonfiction, but hardly fiction."

"I guess," I say as I tap the envelope on the table, sliding the letter inside from one end to the other. "But it's not as nonfictional as a scientific paper."

"Which is easier?" asks Lois. "Writing a scientific paper or writing a story?"

"I'm not sure that one is easier than another. With a scientific article you have to be absolutely sure you have every fact correct and can back it up with a reference. On the other hand, you don't have to master dialogue to write a paper."

"That's lucky for you," says Ken with a smirk. "I mean, considering how useless you are at dialogue."

"Thanks," I say. "Anyway, for a scientific paper, you have to do the study before you even start to write the article. With fiction, you can just make things up. You don't have to crosscheck every fact. I suppose it's different if you're writing historical fiction. But I think the biggest difference is that you can always get any reasonable scientific paper published somewhere. We all know there's a lot of excellent fiction that never finds a home."

"Yeah, like mine," says Michelle. "I've never understood how you even find the time to write. Aren't physicians supposed to be overworked and on call all the time?"

"It doesn't take all that much time to write a novel if you just work at it a little every day," I say. "You guys know that. I think a lot of people have a novel or two in them but they put off writing because they tell themselves they're too busy. Look at John Grisham. He wrote his first novel while he was practising law full-time and serving as a state congressman."

"And he had two small kids," says Ken. "Don't tell me that was a guy with too much time on his hands." Ken clearly knows this story and likes it. Makes sense. After all, Ken's a lawyer trying to write a legal thriller too.

"There are plenty of physicians who find the time to write fiction," I say.

"Michael Crichton," says Michelle.

"Somerset Maugham," says Lois.

"A lot of them gave up practising medicine though," says Ken.

"Not all of them," I say. "Look at Vincent Lam. He works as an emergency doc and he just won the Giller Prize."

"William Carlos Williams was a pediatrician," says Lois.

"Yeah, but he was only a poet, not a real writer," I say, with a glance at Lois. She also dabbles in poetry (or meta-poetry characters and even inanimate objects in her poems often complain about the metre or the rhyme scheme).

"Ha ha ha," she says and pretends to toss her wine at me. "I'll have you know he wrote plenty of fiction."

"About wet wheelbarrows?" asks Ken. Lois sticks her tongue out at him.

From the Division of Neurology, Royal University Hospital, Saskatoon SK, Canada. Received February 12, 2007. AcCePted in Final form February 24, 2007. Reprint requests to: Department of Neurology, Royal University Hospital, 103 Hospital Drive, Saskatoon, Saskatchewan, S7N 0L8, Canada. 
"The thing about writing is that you just have to take it seriously and do it. Practice makes perfect or at least better. Remember that story about the novelist and the neurosurgeon?" I ask.

"No," says Ken. "What story?"

"Well, the writer's introduced to a famous neurosurgeon at a party and when he learns she's a writer, the surgeon says, 'I've often considered writing novels when I retire from neurosurgery.' And the writer says, 'Oh, I've often considered taking up brain surgery when I retire from writing.",

They laugh. "I think that story was about Margaret Laurence," says Michelle.

"Guys, we should get down to business," says Lois. "Am I the only one who's written anything this month?"

"I haven't finished mine," I say. "But I'm working on something. I'm not really sure what it is. It's kind of a short story about what we do here."

"You mean about us?" asks Michelle.

"Well, in a way," I say.

"You'll have to change our names," says Lois.

"Yeah, and our personalities," says Michelle.

"If he changed our names and our personalities," asks Ken, "how would it be about us?"

"It's fiction," I say. "Fiction isn't about anybody."

"Or it's about everybody," says Lois with one of her metafictional smiles.

"You'll have to make us all really good-looking," says Ken.

"If I don't include physical descriptions, readers will just assume you're really good-looking. If you're nice to me, I'll leave out details like, 'Ken patted his monstrous belly.' I'm just not sure what this story-in-progress is. If you write fiction about the non-fiction of writing fiction, is that fiction, or creative nonfiction, or meta-fiction, or what?"

"Creative non-meta-fiction," suggests Michelle.

"Creative meta-non-fiction," says Lois.

"In your case," says Ken, "probably non-creative meta-nonfiction."

"Gee, thanks pal," I say.

"Any time," says Ken (patting his monstrous belly).

"But how can you write a story about our meetings?" asks Michelle. "We just sit around and discuss our writing. There's no tension there. You need some kind of suspense to make a story." She's slid a fingernail under a corner of the seal on my envelope and is teasingly picking at it.

"Yeah, I suppose," I say. "I'm not even sure I'm cut out to write fiction. And why did I start with a novel? If I'd stuck to short stories, I might have some published by now. Instead, I worked two years on a novel that may never see the light of day."

Ken says, "Maybe you should've started with haiku and worked up."

"Dr. Seuss," shouts Michelle.

"Dr. Seuss?" I ask.

"Another doctor-writer."

"Dr. Seuss wasn't a physician," says Lois.

"Perhaps a meta-physician," I offer.

"Deep," says Ken.

Michelle laughs. She's about the happiest person you're likely to meet outside of a circus and she was born and raised right in this city yet she writes bleak tales about misunderstood immigrants who usually end up either dead or imprisoned. "Well, I like your novel," she says. "It makes me laugh." (Most things do.) "One thing I like is that you always tell what the characters are eating and drinking. I enjoy food and I want to know what people are eating." She takes a sip of her Eaglehawk shiraz and pops another garlic-stuffed olive into her mouth. "By the way," she says, "I thought John Grisham had four kids."

"See, that illustrates my point about checking facts in nonfiction. Here in conversation it doesn't really matter whether we know how many kids he had or whether he was a state congressman or a state senator. But in a non-fiction article, you'd have to double-check your facts and get them right."

"Wouldn't you want to get them right in fiction too?" asks Michelle.

"Well, yeah, if the narrator's saying it. But it mightn't really matter if a character in a story got something wrong. The reader would just think the character was dumb or misinformed. In fact, you might purposely have a character get a fact wrong for a reason that pops up sixty pages on."

"When one of John Grisham's children enters the story?" asks Michelle.

"Exactly," I say.

"What does it matter how many kids John Grisham has?" asks Lois.

"It matters to John Grisham," says Ken.

"And to Mrs. Grisham," says Michelle.

Lois rolls her eyes as if to say, 'Why do I put up with them?' and asks me, "If you're so anxious to get your fiction in print, why don't you publish a story in a medical journal?"

"Medical journals don't publish fiction."

"Why not?" asks Michelle.

That gives me pause for a moment. "I'm not sure. They just don't. It's not what they're for."

"If they did," says Michelle, "people might find them more interesting and read more of the scientific articles."

"Maybe," says Ken. "But I think we're avoiding a matter at hand. There's a certain envelope here that needs opening." $\mathrm{He}$ holds it aloft like it's Liberty's torch.

"I don't want to open it," I tell him. "You guys open it." Michelle snatches it from him and begins to tear. "No, wait," I say. "I don't want to see this. I'll go outside."

"Suit yourself," says Ken. "We'll call you back in when we have a verdict."

I step outside and the screen door slams behind me. I guess if this were really my story, I'd be able to tell you whether the world outside greets me with the wintry wind of icy rejection or the syrupy sunshine of warm acceptance. I draw a deeply alliterative breath. And I wait.

\section{Andrew Kirk Saskatoon, Saskatchewan}

Andrew Kirk is a neurologist at the University of Saskatchewan. Since 2003 he has been a member of Doing The Write Thing, a writers group in Saskatoon. His first novel, Double Album, is not yet published. 